\title{
HPV vaccination: the beginning of the end of cervical cancer? - A Review
}

\author{
Ana Paula Lepique/ ${ }^{+}$, Tatiana Rabachini, Luisa Lina Villa \\ Instituto Ludwig de Pesquisa sobre o Câncer, Rua João Julião $2451^{\circ}$ andar, 01323-903 São Paulo, SP, Brasil
}

\begin{abstract}
Human papillomavirus (HPV) is responsible for all cases of cervical cancer, as well as a great percentage of other anogenital tumors and oropharyngeal tumors. Since the main etiologic factor for these diseases is a virus, prophylactic measures are the best way to reduce the burden caused by the infection and associated disease. This review brings up to date information on the two commercially available prophylactic HPV vaccines against $H P V$, as well as presenting the ongoing research on HPV peptide, protein and dendritic cell based therapeutic vaccines.
\end{abstract}

Key words: human papillomavirus - anogenital cancers - prophylactic vaccine - therapeutic vaccine - clinical trial

Human papillomavirus (HPV), the most common newly acquired, sexually transmitted infection worldwide, infects only in the United States $75 \%$ of sexually active individuals in their lifetimes (Koutsky 1997). The high-risk HPV types, the most common of which are HPV 16 and 18, cause cervical and other anogenital cancers (Schiffman \& Kjaer 2003), as well as some head and neck cancers (D'Souza et al. 2007). The low-risk types, the most common of which are HPV 6 and 11, cause genital warts (Brown et al. 1999), low-grade cervical dysplasias and recurrent respiratory papillomatosis, a rare but potentially fatal disease (Syrjanen 2005).

Most of our understanding of HPV and carcinogenesis is derived from studies of women and cervical cancer. This literature has clearly demonstrated that HPV infection is the primary cause of cervical cancer and plays a central role in cervical carcinogenesis (Clifford et al. 2003). Prospective studies conducted among women indicated that women with persistent oncogenic type HPV infections are at a significantly greater risk of developing cervical intraepithelial neoplasia (CIN) compared with women who are only transiently infected (Bosch et al. 2008). In addition, women who are persistently HPV positive are four times more likely to have a persistent lesion of the cervix. Median duration of oncogenic infections is approximately seven-nine months and is longer than infection with non-oncogenic HPV types. Infection with other sexually transmitted diseases influences progression to disease. Finally, recent data have suggested that HPV viral load is related to progression of HPV infection to CIN 2-3 and to persistence of these premalignant lesions (Wang \& Hildesheim 2003).

Different HPV types are related to different cervical lesion grades. HPV16, found in about half of cervical tumors examined, is strongly associated with CIN,

+ Corresponding author: alepique@1udwig.org.br

Received 6 February 2009

Accepted 13 February 2009 carcinoma in situ and cervical cancer. This type is also highly associated with the precursor lesions, anal squamous intraepithelial lesions and anal cancer in men. HPV16 is associated with more than $50 \%$ of oropharyngeal cancers. Other HPV high-risk types are also linked to a series of tumors and its precursor lesions in humans (Giuliano et al. 2008).

\section{Prophylactic vaccines}

New prophylactic HPV vaccines have the power to prevent many HPV infections, thus reducing the burden of HPV-associated diseases. Two vaccines have been developed, a quadrivalent vaccine that protects against HPV 16, 18, 6 and 11 and a bivalent vaccine that protects against HPV 16 and 18. Both vaccines are composed of HPV L1 proteins that have spontaneously self assembled into virus-like particles (VLPs). However, they have different manufacturers, valencies, adjuvants and are produced in different types of cells (Table I). Both are administered by intramuscular injection, in three doses ( 0,1 or 2 and 6 months). The types and levels of immune responses generated by both vaccines may vary and have not been thoroughly analyzed so far. Moreover, since different assays are used to measure the vaccine-induced antibody responses, no direct comparison can be made. Suffice to say that both vaccines have shown very high efficacy to prevent infection and disease caused by the types included in the vaccine, as described below.

Efficacy of prophylactic HPV vaccines - Since 1998, several clinical trials of two prophylactic HPV vaccines have being conducted in different countries including about 50,000 individuals. All of the trials were blinded, randomized and placebo controlled trials of young women (mean age 20). Other trials are still ongoing that include adult women and men. Participants were recruited at multiple sites in Europe, North America, South America, Asia and Australia. Prophylactic efficacy was measured considering HPV infection and disease endpoints, particularly CIN2 or worse (CIN2+) for the bivalent and quadrivalent vaccines, as well as vulvar intraepithelial neoplasia (VIN) or vaginal intraepithelial neoplasia and genital warts, for the quadrivalent vaccine only. The per- 
protocol populations included women who were naïve at baseline to HPV 16 and 18, or to HPV 6, 11, 16 and 18 , as determined by serology testing for presence of HPV type-specific antibodies or polymerase chain reaction (PCR) testing of genital samples for the presence of HPV DNA (Harper et al. 2004, Villa et al. 2005). For both the bivalent and quadrivalent vaccines, results of different trials allow for the examination of broad trends in efficacy in preventing HPV 6/11/16/18-related disease in several groups of patients categorized according to their HPV status at baseline. The quadrivalent vaccine was $100 \%$ effective in reducing the incidence of HPV 6/11/16/18-related disease in women who were serologically and DNA PCR negative at baseline to the relevant HPV type as well as in women who had been previously exposed to at least one vaccine HPV type at enrollment, but had no ongoing HPV infection (i.e., seropositive but HPV DNA negative by PCR) (Future II Study Group 2007, Garland et al. 2007). However, there was no clear evidence of protection from disease cause by HPV types for subjects that were HPV DNA positive by PCR and/ or seropositive at baseline (Ault 2007, Joura et al. 2007). Similar results were obtained for the bivalent vaccine (Harper et al. 2006). In fact, vaccination of HPV16/18 DNA positive women does not enhance clearance of the viral infection (Hildesheim et al. 2007). In a recent publication of a phase III trial, this bivalent vaccine showed 90\% prophylactic efficacy against CIN2+ associated with HPV 16 or HPV 18 (Paavonen et al. 2007). In a combined according to protocol analysis of women with evidence of current or past infection with one or more of the vaccine targeted HPV types, the quadrivalent vaccine was $100 \%$ effective at preventing CIN2+ or AIS associated with vaccine targeted types to which the vaccine had no evidence of prior exposure (Ault Future II \& Study Group 2007). Thus prior or prevalent infection by one type does not appear to influence the effectiveness of the vaccine against other types.

Results on protection against infection by non-vaccine HPV types have been published and reviewed in Ault (2008). Cross-protection against incident infection with HPV types 45 and 31 has been observed for the bivalent vaccine (Harper et al. 2006). Efficacy of this vaccine against persistent infection with 45 and 31 has also been reported (Paavonen et al. 2007). However, there was no significant protection against types 33,52 or 58 . Data from the phase III trials of the quadrivalent vaccine reported at scientific conferences indicates a partial prophylactic efficacy against persistent infection caused by 10 non-vaccine HPVs, including those mentioned above. Importantly, significant but partial protection against incident CIN2/3 associated with non-vaccine types was also noted. Further studies to better understand the significance and durability of these responses are warranted. It is possible that the best and most efficient responses will be obtained with multivalent vaccines against a larger number of genital HPV infections which are presently under development.

Safety of prophylactic HPV vaccines - VLPs are noninfectious protein subunit vaccines and therefore might be expected to have safety profiles similar to other protein subunit vaccines such as tetanus or hepatitis B vaccines. Both vaccines were generally well tolerated and there were very few dropouts due to vaccine-related symptoms (Harper et al. 2004, Villa et al. 2005). The most common vaccine related adverse events were local transient mild to moderate pain and erythema at the site of injection. These reactions were significantly elevated compared to placebos with both vaccines. It is noteworthy that neither local nor systemic symptoms increased with each subsequent dose and symptoms were not more severe in women with evidence of prior exposure to one of the vaccine types (Garland et al. 2007). The proportion of women experiencing serious adverse events, whether deemed to be related to the vaccine or not, was much the same in VLP vaccines and controls. Although the women were encouraged to use reliable methods of birth control, pregnancies did occur in numerous women enrolled in the trials. Overall, there was no difference in pregnancy outcomes, such as proportions of live births, spontaneous abortions or congenital abnormalities, between VLP vaccines and controls for either vaccine (Future II Study Group 2007, Paavonen et al. 2007).

Substantially more information on the performance of the vaccine in males, older women and immunosuppressed populations should become available in the next few years as clinical trials in these groups are completed.

TABLE I

Comparison of prophylactic HPV VLP vaccines

\begin{tabular}{lcc}
\hline & Quadrivalent $^{a}$ & Bivalent $^{b}$ \\
\hline Manufacturer & Merck Sharp \& Dohme & GlaxoSmithKline \\
VLP types & $6 / 11 / 16 / 18$ & $16 / 18$ \\
Dose of L1 protein & $20 / 40 / 40 / 20 \mu \mathrm{g}$ & $20 / 20 \mu \mathrm{g}$ \\
Producer cells & Saccharomyces cerevisiae (yeast) expressing L1 & Trichoplusia ni insect cell line \\
& & infected with L1 recombinant baculovirus \\
Adjuvant & $225 \mu$ g aluminum hydroxyphosphate sulfate & $500 \mu$ galuminum hydroxide, 50 $\mu \mathrm{g}$ \\
Injection schedule & $0,2,6$ months & 3-O-deacylated-4'-monophosphoryl lipid A \\
\hline
\end{tabular}

$a$ : commercially designated as Gardasi ${ }^{\mathrm{TM}} ; b$ : commercially designated as Cervarix ${ }^{\mathrm{TM}}$. 
Immunogenicity and sustained protection of prophylactic HPV vaccines - Since the VLP vaccines were designed primarily to protect by inducing virion neutralizing antibodies, type specific antibody responses to the VLPs have been the primary focus of immunogenicity studies. Both vaccines were shown to be highly immunogenic in the clinical trials, resulting in essentially $100 \%$ seroconversion in the different populations studied. Peak geometric mean antibody titers (GMTs) were approximately 10-100-fold higher that the GMTs generated after natural infection (Harper et al. 2004, Villa et al. 2006a, Garland et al. 2007). However, it is important to note that different assays were used to measure the antibody responses to the two vaccines. Therefore, quantitative comparisons of the antibody responses to the two vaccines cannot be made based on the published results. Titers for both vaccines generally peaked one month after the third dose (given at month 6), declined over the next year and then remained relatively stable for the duration of follow up. Boosting with Gardasil at year five was shown to induce a strong recall response, with titers for each type at least as high as the peak titer following the initial series of vaccinations (Olsson et al. 2007). Thus the vaccine induces the expected B cell memory response which is a property of vaccines with durable immune responses. Although the long term persistence of stable antibody levels is an encouraging finding, the antibody levels needed to prevent infection or disease are currently unknown.

Currently, the duration of protection provided by the HPV vaccines is not known. However, long-term followup studies have shown that efficacy is maintained for at least five years (Harper et al. 2006, Villa et al. 2006b, Olsson et al. 2007) and modeling studies suggest protection may last much longer. The true duration of protection offered by a vaccine is almost never known until the vaccine has been in use for many years. It is not known what level of antibodies indicates an individual's ability to fend off HPV infection, but the available data do suggest that HPV vaccines would provide a lengthy period of protection, likely to usher a vaccinated individual through the years of highest infection risk and beyond. Additional studies are ongoing to verify these projections.

Because HPV infection is most common among young, sexually active individuals, the vaccine will be most effective if administered to individuals previous to onset of sexual activity. It was therefore critical to demonstrate the safety and immunogenicity of the HPV vaccines in younger individuals than those women in whom the vaccine efficacy has been demonstrated. In two immunogenicity bridging studies, the quadrivalent vaccine was shown to be safe and immunogenic in adolescent boys and girls (9-15 years old) (Block et al. 2006, Reisinger et al. 2007). The antibody response to the vaccine was approximately two-fold higher in this age group than the responses in young women. Similar profiles of safety and immunogenicity in adolescent girls and young women were described for the bivalent vaccine (Pedersen et al. 2007).
$H P V$ vaccines introduction and implementation Based on its demonstrated clinical efficacy and favorable safety profile, HPV prophylactic vaccines are being introduced in many countries around the world. In several developing countries, including among other Brazil, Chile, Mexico and Peru, the Quadrivalent HPV 6, 11, 16, 18 vaccine is in use for more than one year. The rapid approval and launch of such vaccines are a clear indication that governments and policy makers are aware of the expected impact on the prevention of one of the most common causes of female mortality worldwide. However, incorporation of HPV vaccination in the public health sector is still to be seen in the developing world, mostly due to vaccine cost. HPV vaccine implementation will also depend on local infrastructure for vaccine delivery to the initial target population during the window of highest vaccine efficacy, i.e., prior to sexual exposure. Furthermore, introducing HPV vaccines in the present cervical cancer control system is hampered by the fact that secondary screening with Pap tests (or HPV DNA testing) will still be required to detect cervical cancers and pre-cancers caused by non-vaccine HPV types. Ongoing cost-benefit studies and negotiations between governments, the private sector, and non-governmental organizations, may enable some of the developing countries, where the vaccine is most needed, to implement the necessary programs. Education of physicians, policy makers, parents and adolescents will be crucial for delivering HPV vaccines which ultimately will result in the reduction of cervical cancer rates and other HPV-related diseases worldwide. Vaccine acceptance is largely determined by health beliefs, such as the individual's perceived susceptibility to the disease, vaccine characteristics, such as cost and efficacy, and obstacles to obtaining the vaccine. Health perceptions are expected to play a major role in the acceptance of HPV vaccine, as is the fact that the vaccine raises the morally and politically charged issue of adolescent sexual behavior. Physician attitudes are extremely influential to both parents and adolescents and perception that the physician regards the HPV vaccine as important and recommended will be a critical step towards vaccine acceptance. Altogether, education of physicians, parents and adolescents will be crucial for delivering HPV vaccines to target populations during the window of highest vaccine efficacy, prior to sexual debut.

Despite these excellent efficacy results, it may take some time before these vaccines are administered to the general population worldwide. Moreover, women will still be at risk for developing cancers caused by other HPV types not included in the vaccine and hence screening and monitoring strategies will be required. Finally, since at present the durability of these vaccines have been evaluated only for up to five years for the quadrivalent vaccine (Villa et al. 2006b) and 6.5 years for the bivalent vaccine (Harper et al. 2006, Schwarz \& Leo 2008), monitoring of antibody levels and high grade disease caused by the vaccine HPV types in sentinel groups of immunized individuals will be required over the next decades (Lehtinen et al. 2006). It is important to stress that disease outcomes should be recorded since at pres- 
ent there is no immune correlate and the importance of serum antibody levels is simply not known. To achieve this, standardized methodologies that measure total serum antibody, neutralizing antibody and type specific antibody concentrations will be necessary. However, at present neither HPV serological assays nor HPV DNA tests can be used as clinically relevant tools for individual patients. These assays will require the establishment of an international standard(s) with an arbitrarily assigned unit measure or international units (Ferguson et al. 2006, WHO 2008).

The availability of two prophylactic HPV vaccines will require thorough considerations about monitoring and surveillance of those vaccinated and the general population, respectively (Stanley \& Villa 2008). Vaccinated populations should be followed-up for long-term safety, sustained immune responses and vaccine disease efficacy (Dillner et al. 2007). Effective monitoring will benefit from linkage of vaccination history and screening history, as well as precise measurement of HPV infection, both DNA and serological testing.

\section{Therapeutic HPV vaccines}

The success of the prophylactic vaccines against HPV is clear. However, these vaccines are not and will not be available in the short run, as public immunization program, to the population of developing countries due to economic restrictions and other issues. Moreover, these vaccines show no therapeutic effects regarding the virus infection and the associated lesions, which affect hundreds of millions of individuals worldwide. The time frame between infection and tumor development is long, one to two decades, so that for women already infected, the prophylactic vaccine will be not useful. In addition, while prophylaxis is achieved by developing a potent immune response against the viral capsid protein (L1), a cellular response against the early proteins E6 and E7 is required to eliminate already infected cells. For the reasons stated, research leading to the establishment of a therapeutic vaccine against high risk HPV, mainly 16 and 18 , the most prevalent in cervical cancer bearing patients, is very important.

A great and obvious advantage in tumors associated to HPV, when we think of therapeutic vaccines, is that the target antigens are not self, they are viral proteins, and their expression is absolutely necessary for the transformed phenotype of the tumor cells. E6 and E7 HPV proteins are expressed in all tumor cells and inhibition of their expression leads the cells to senescence (AlvarezSalas \& DiPaolo 2007). Therefore, chances of escape mechanism by antigen loss are very low when considering HPV associated tumors. Moreover, no cells, except the tumor cells, would be affected by the therapy.

The main challenge for the efficacy of therapeutic vaccines is to overcome tolerance. Mechanisms of immune evasion are present from the productive infection to the tumors. During productive infection, viral protein expression is very low, due the promoter regions, which a relatively weak one and rare codon usage by the viral genome (Phelps \& Howley 1987, Müller 2005). Low protein expression, together with low expression of the antigen presenting machinery, like TAP, Tapasin, LMP2 and LMP7 limit proteolyses by the proteasome system and antigen presentation by MHC-I complex (Ritz et al. 2001). Another important mechanism of evasion is the virus cycle itself, which is intimately linked to the keratinocyte differentiation program, in such a way that early low protein expression and DNA replication takes place in cells exposed to the antigen presenting cells. Capsid proteins and virion assembly take place in the cells close to the end of the differentiation program and far from immune cells (Frattini et al. 1997). Moreover the viral life cycle does not cause cytolysis; instead new virions are eliminated with naturally dead cells, in a process without of inflammation. HPV proteins also inhibit antivirus cell responses by decreasing TLR 9 gene transcription (Hasan et al. 2007), recruiting Histone Deacetylase complex to IRF-1 bound to its target promoters (Park et al. 2000) by inhibiting IRF-3 (Ronco et al. 1998).

All these mechanisms are, obviously, counteracted by the host immune responses, and it is important to remember that most infections and low grade lesions are cleared spontaneously by the host immune system (Schlecht et al. 2003). Specifically, two conditions must be met for tumor development: persistent infection and integration of viral DNA into the host genome. Persistent infection, most always asymptomatic, often implicates tolerance, which may be achieved by the mechanisms described before, or by selection as response to the antivirus innate response.

HPV associated lesions also display mechanisms of immune evasion, which are not as well understood as the mechanisms generated by infection in the host cell (Stanley et al. 2007). Tumor cells express different cytokines that recruit and induce differentiation of leukocytes into suppressor cells. Indeed in patients, it was observed that higher macrophage numbers correlate with higher grade cervical lesions (Hammes et al. 2007, Mazibrada et al. 2008). The chemokine receptor CCR 2 has been shown to be responsible for the recruitment of macrophages to lesions in CCR2-deficient K14-HPV/E(2) mice (Pahler et al. 2008). CD4 regulatory T cells were found in women with cancer, while asymptomatic women with HPV DNA displayed a CD4Th1 response against HVP antigens. Lymphocytes from asymptomatic women secreted IFN $\gamma$, TNF, IL-2, IL-5 and IL-10 in response to HPV antigens. On the other hand, lymphocytes from women with tumors had very weak responses and secreted only IL-10 in response to the same antigens (de Jong et al. 2004). TGF $\beta$ is secreted in the tumor environment, although there is no consensus about expression levels in the literature (Kirma et al. 2007, Diaz-Chavez et al. 2008). Together with IL-10, this cytokine is an inducer of regulatory phenotype on T cells (Niederkorn 2008, Poggi \& Zocchi 2008, Wan \& Flavell 2008).

An ideal anti-cancer therapeutic vaccine should be able to elicit cytotoxic anti-tumor specific responses, tumor infiltration by effectors cells and tumor volume reduction or elimination. Several strategies have been used to achieve these objectives with different degrees of success. Use of adjuvants and immunostimulators with the antigens is an important tool, as well as the form of 
antigen presentation. Up to date, use of fusion proteins, long peptides and dendritic cells based vaccines have been trialed. In general, vaccines have been developed against HPV16, once this is the most prevalent type of HPV in tumors, accounting for more than $50 \%$ of the cases worldwide (de Vuyst et al. 2008). Ongoing and previous therapeutic vaccine clinical trials against HPVassociated lesions in humans are listed in Table II.

Peptide and protein based HPV vaccines - Overlapping long peptides spanning the entire HPV16 E6 and E7 protein sequences vaccine together with Montanide ISA51, an adjuvant similar to a non complete Freund's adjuvant, have been tested for safety and efficacy in women with lower genital tract carcinomas (Kenter et al. 2008), as well as in women who underwent radical hysterectomy because of confirmed HPV16 caused cervical carcinoma (Welters et al. 2008). This study was motivated by tests in mice, where short E7 peptide $\mathrm{E}_{49-57}(9$ amino acid residues) and long E7 peptide $\mathrm{E}_{43-77}$ (35 residues) were compared with and without the use of different adjuvants (Zwaveling et al. 2002). In mice, the long peptide was more efficacious than the short for generation of immune responses and protection against tumor growth, generating both CD4 Th1 and CD8 anti-E7 responses (Zwaveling et al. 2002). The long peptides are probably more efficiently internalized and processed by antigen presenting cells than short peptides; therefore better immune responses are generated against the long ones. In these trials, 22 mer (Kenter et al. 2008) or 25-35 mer (Welters et al. 2008) overlapping peptides spanning the complete sequence of HPV16 E6 and E7 proteins were used for immunization. In both cases, immunization induced IFN $\gamma$ production by T cells in response to both E6 and E7 peptides. In one of the trials, researchers also observed IL-5 secretion in response to some of the peptides (Welters et al. 2008). In this case specifically, six women were enrolled and three of them remained free of disease during the follow-up, while two had recurrence and one was lost during follow-up. This work also showed that while the vaccine induced specific effector CD4 $\mathrm{T}$ cell responses, it boosted CD4 regulatory pre-existing $\mathrm{T}$ cells (Welters et al. 2008). Overall these vaccines were well tolerated, never causing reactions stronger than swelling of the injection area, redness and local pain.

Fusion proteins have been used in a number of studies of immunization against HPV and its associated lesions. Bacterium heat shock proteins (hsp) elicit strong immune responses in mammals simultaneously activating innate and adaptative responses by leading antigen presenting cells to full maturation, migration to lymph nodes, expression of co-stimulatory molecules and secretion of pro-inflammatory cytokines (Harmala et al. 2002, Srivastava 2002). Fusion of E7 and hsp has been used in four trials. The fusion of HVP16 E7 proteins with Mycobacterium bovis BCG hsp65 was previously tested in the TC-1 tumor mouse model, with $100 \%$ efficacy in mice inoculated with tumor cells (Chu et al. 2000). Based on these results, phase I and II clinical trials have been conducted in women with biopsy-proven high-grade cervical intraepithelial neoplasia and persistent post-biopsy

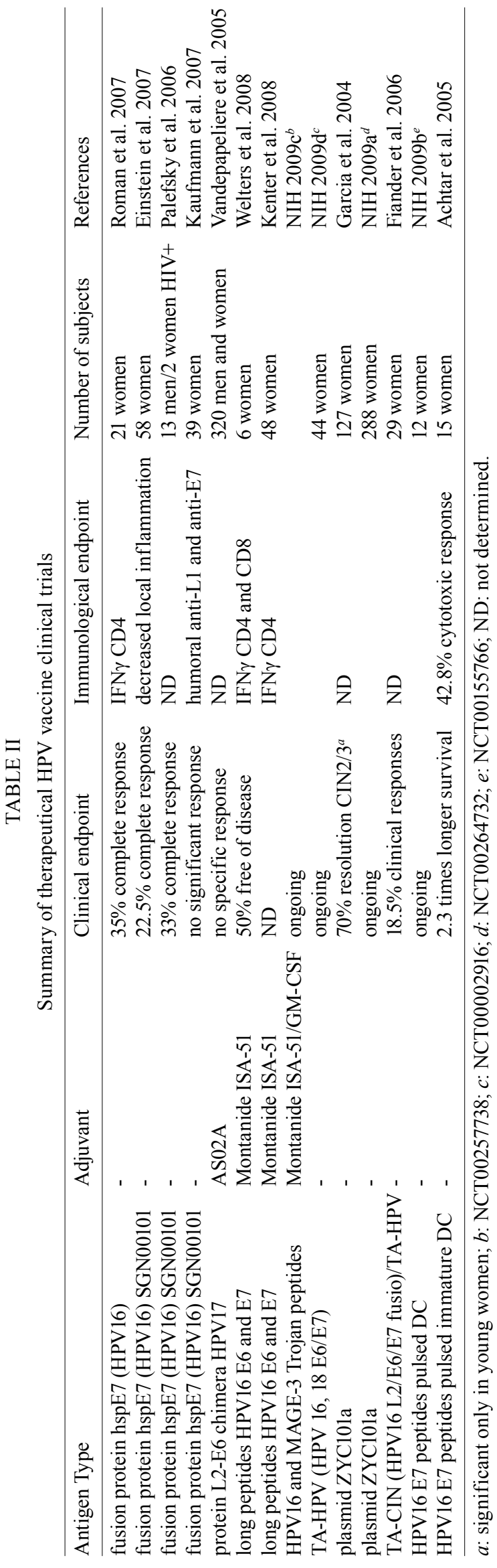


lesions (Roman et al. 2007), in women diagnosed with CIN 3 (Einstein et al. 2007) and in HIV positive men and women with high grade anal intraepithelial neoplasia (Palefsky et al. 2006). In these trials, an average of $50 \%$ of the patients treated had stabilization of the disease after vaccination; complete response was achieved in an average of $25 \%$ of the patients, about $20 \%$ of the patients had partial responses and $1-2 \%$ of the treated patients presented progression of disease. Although these are promising results, not all treated patients were positive for HPV16, which means part of the responses obtained are not specific towards HPV16, but may be due to the immune stimulatory effects of the heat shock protein itself. Further studies on this vaccine will be necessary.

Another type of fusion used is the fusion between an early HPV protein, mainly E7, but in some cases E6 and a capsid protein, usually L1. The L1/E7 chimeras are composed by the carboxy-terminally truncated L1 protein fused to as many as 60 amino acids from the HPV16 E7 protein. This chimera forms virus-like particles that enter the cell and are found in the cytoplasm and endoplasmic reticulum, suggesting that they can enter the MHC-I antigen presentation pathway (Schiller \& Roden 1995, Zhou et al. 1995, Müller et al. 1997). In vitro, these chimeras induce IFN $\gamma$ expression on T cells, as well as cytotoxic responses (Kaufmann et al. 2001). A clinical trial was conducted in women positive only for HPV16 with diagnosed CIN2/3. The vaccine was well tolerated with mild and few adverse effects. However, the immune responses obtained were mostly antibodies against L1. The lesion regression observed in the vaccinated group of this study was no different than that observed in the placebo treated women, which led the authors to the conclusion that this vaccine was not efficacious for treating women with HPV associated lesions. Further studies are warranted.

Chimeras were also used in trials in combination with AS02A as adjuvant, in these cases a chimera of HPV6 L2-E7 were used to vaccinate patients with anogenital warts (Vandepapeliere et al. 2005). In this trial no differences were observed between the vaccinated and placebo groups. Wart regression in both groups was spontaneous and not related to the vaccine. In a still different approach, a fusion of HPV16 E6/E7 proteins were administrated to women with CIN1, 2 or 3, as well as healthy subjects, using ISCOMATRIX ${ }^{\mathrm{TM}}$ as adjuvant. ISCOMATRIX $^{\mathrm{TM}}$ is composed of a purified fraction of saponin, cholesterol and a phospholipid and has been used in trials for immunization with other antigens, for instance HCV (Lin et al. 2008). Regarding HPV infection, a phase I trial was performed to observe safety and immunogenicity of the vaccine (Frazer et al. 2004). Most vaccinated women responded to the vaccine, although $71 \%$ displaying CD4 and 41\% displaying CD8 responses. Further studies will be necessary to show if these responses are able to cause clinical regression of lesions.

Viral vector based HPV vaccine - Modified or recombinant Vaccinia virus has been used as strategy for immunization in several models. Attenuated or recombinant Vaccinia vectors are an efficient way to deliver and express recombinant genes into the host cells for immuni- zation (Sutter \& Moss 1992). A withdraw of this system shared by other biological vectors is that the immune responses against the vector may compete with immune responses against the target antigen. Moreover, if more than one immunization is necessary, there is a high chance that the host will neutralize the vector before it has the chance to deliver the target gene(s) to an antigen presenting cell. A trial using recombinant Vaccinia virus encoding HPV16 and HPV18 E6 and E7 genes for immunization of women with cervical carcinoma stage Ib or IIa is ongoing (NCT00002916; NIH 2009d).

DNA based HPV vaccine - Plasmid DNA encoding HPV16 and HPV18 E6 and E7 fragments encapsulated in small biodegradable particles has been used for immunization of women with CIN2/3 lesions. This is an ongoing trial, which is enrolling young women (13-25 years old) with abnormal Pap smear, colposcopically visible lesion suspected to he high-grade, or have CIN $2 / 3$ consensus pathology diagnosis (NCT00264732; NIH 2009a).

Dendritic cell based HPV vaccine - Dendritic cells are the most efficient or so called professional antigen presenting cells. When properly activated, these cells are able to induce strong effector T cell responses and memory. This concept has been exploited to develop vaccines against different human malignancies (Melief 2008). In patients with advanced cervical cancer (recurrent disease or with metastases), treatment with autologous immature dendritic cells pulsed with the HPV16 E712-20 peptide induced IFN $\gamma$ secretion and specific cytotoxic responses in peripheral blood mononuclear cells in six of the 15 patients. Patients with positive immune responses had 2.3 (8.6-20.3 months) longer survival rate than the placebo treated group, as well as showing longer progression free survival periods (1.8 fold, 3.5-6.5 months) (Achtar et al. 2005). In this study, two women suffered grade III adverse effects, anemia and thrombocytopenia, which was considered an effect of the disease instead of the immunization protocol. Efficacy of autologous dendritic cells loaded with HPV16 E7 peptides injected in the inguinal lymph nodes of patients with advanced cervical cancer is under study (NCT00155766; NIH 2009b).

Experimental HPV vaccines - animal models - Besides the therapeutic vaccine modalities in trial in humans, several others are being developed and tested pre-clinically in mice. DNA vaccines have been tested with different strategies to enhance immune responses against HPV antigens. DNA is potentially an excellent form of antigen delivery once it promotes antigen synthesis inside the antigen presenting cells favoring the antigen presentation by MHC-I pathway. However naked DNA is very poorly immunogenic and strategies for adjuvancy must be considered in these cases. Usually plasmids used for immunizations against HPV carry E7 or E6/E7 gene portions. A fragment coding the PADRE (pan-DR epitope) peptide has been used to enhance CD4 responses to the antigen, in some cases together with other adjuvants like $\mathrm{CpG}$ (Kim et al. 2008). In plasmids it is also possible to construct fusions, like hsp and E7, as mentioned before, which enhances the antigen presenta- 
tion by MHC-I (Chen et al. 2000); or fusion with lysosomal associated membrane protein type-1 (LAMP-1), which targets the antigen to endosomal and lysosomal compartments facilitating MHC-II presentation and $\mathrm{T}$ helper responses (Wu et al. 1995). Many other DNA vaccination strategies and described mechanisms could be mentioned here. The main message however is that although these vaccines are $100 \%$ protective against tumor models in animals, most of these strategies have not been tested and may not work in humans.

Protocols of animal immunization with peptides include, besides the models tested before that resulted in clinical trials in humans, use of adjuvants like Montanide and CpG (TLR9 ligand) or combination of both resulting in robust protective immune response in mice (Hirunpetcharat et al. 2003, Kumar et al. 2004). VacciMax together with PADRE and E7 peptide induce robust immune responses and protection in mouse tumor model (Daftarian et al. 2006).

Viral and bacterial vectors have also been tested in mouse models. Vaccinia recombinant vaccines encoding E7 in fusion with calreticulin, a protein with ability to amplify tumor-specific $T$ cell-mediated immune responses, induced IFN $\gamma$ secretion by CD8 cells and robust protection against tumors in mice, even when compared to other vector and not only the immunization controls (Hsieh et al. 2004). Another model in test is modified the Listeria monogenesis, a facultative intracellular bacteria taken up primarily by antigen-presenting cells such as macrophages and dendritic cells and target the lysosomes, therefore exposing antigens to be presented by MHC-II. Listeria developed for immunization against HPV expresses E7 fused either a truncated form of listeriolysin O (LM-LLO-E7), or fused to a fragment of the ActA protein (LM-ActA-E7), both of which have a PEST domain within their sequences, promoting rapid degradation of these proteins in the citosol, facilitating antigen presentation through MHC-I. Indeed, in mice, this type of immunization causes regression of HPV16-positive solid tumors (Gunn et al. 2001, Sewell et al. 2004, Hussain \& Paterson 2005).

Prophylactic HPV vaccines are successful and have the potential to greatly reduce cervical cancer and other HPV associated diseases in the future, mainly once it is adopted as public immunization program by most countries. On the other hand, much effort has been put on the development and establishment of therapeutic vaccines against HPV chronic infections and diseases. Although responses are still modest in humans, many of the examples given in this review have the potential to develop into robust vaccines. In the mean time, a continuous educational of physicians, policy makers, parents and adolescents will be crucial for delivering HPV vaccines which ultimately will result in the reduction of cervical cancer rates and other HPV-related diseases worldwide. Both primary and secondary screening for women either based on Pap or molecular tests, must be available. Ongoing studies on the natural history of HPV infections in men and prophylactic HPV vaccine efficacy should contribute to the design of prevention strategies of this most common infection in this gender as well. Altogeth- er, with the knowledge accumulated about HPV carcinogenesis, it is reasonable that therapeutic HPV vaccines should soon be in the course of action to reduce the significant burden of disease caused by HPV worldwide.

Lack of record linkage in many settings is one of the main obstacles for an effective surveillance program, though other surveillance activities can make contributions to assessing HPV vaccine efficacy, including information from organized screening programs and phase IV studies. Importantly, loss of screening performance may occur because of the expected reduction in cervical abnormalities in vaccinated populations. In this scenario, HPV testing has the potential to perform better as a primary screening test, followed by cytology for triage of HPV-positive cases (Franco et al. 2006).

\section{REFERENCES}

Achtar MS, Ibrahim R, Herrin E, Gause B, Steinberg S, Grollman F, Rahma O, Berstein S, Maruffi C, Berzofsky JA, Khleif SN 2005. Pre-immature dendritic cells pulsed with human papillomavirus 16 E7 peptide vaccine in advanced cervical cancer. J Clin Oncol 23: $2522-2533$.

Alvarez-Salas LM, DiPaolo JA 2007. Molecular approaches to cervical cancer therapy. Curr Drug Discov Technol 4: 208-219.

Ault KA 2007. Human papillomavirus vaccines and the potential for cross-protection between related HPV types. Gynecol Oncol 107 (2 Suppl. 1): S31-33.

Ault KA 2008. Human papillomavirus vaccines: an update for gynecologists. Clin Obstet Gynecol 51: 527-532.

Ault KA, Future II Study Group 2007. Effect of prophylactic human papillomavirus L1 virus-like-particle vaccine on risk of cervical intraepithelial neoplasia grade 2 , grade 3 , and adenocarcinoma in situ: a combined analysis of four randomised clinical trials. Lancet 369: 1861-1868.

Block SL, Nolan T, Sattler C, Barr E, Giacoletti KE, Marchant CD, Castellsagué X, Rusche SA, Lukac S, Bryan JT, Cavanaugh PF Jr, Reisinger KS, Protocol 016 Study Group 2006. Comparison of the immunogenicity and reactogenicity of a prophylactic quadrivalent human papillomavirus (types $6,11,16$, and 18) L1 viruslike particle vaccine in male and female adolescents and young adult women. Pediatrics 118: 2135-2145.

Bosch FX, Burchell AN, Schiffman M, Giuliano AR, de Sanjose S, Bruni L, Tortolero-Luna G, Kjaer SK, Muñoz N 2008. Epidemiology and natural history of human papillomavirus infections and type-specific implications in cervical neoplasia. Vaccine 26 (Suppl. 10): K1-16.

Brown DR, Schroeder JM, Bryan JT, Stoler MH, Fife KH 1999. Detection of multiple human papillomavirus types in Condylomata acuminata lesions from otherwise healthy and immunosuppressed patients. J Clin Microbiol 37: 3316-3322.

Chen C-H, Wang T-L, Hung C-F, Yang Y, Young RA, Pardoll DM, Wu T-C 2000. Enhancement of DNA vaccine potency by linkage of antigen gene to an HSP70 gene. Cancer Res 60: 1035-1042.

Chu NR, Wu HB, Wu TC, Boux LJ, Siegel MI, Mizzen LA 2000. Immunotherapy of a human papillomavirus (HPV) type 16 E7expressing tumour by administration of fusion protein comprising Mycobacterium bovis bacille Calmette-Guérin (BCG) hsp65 and HPV16 E7. Clin Exp Immunol 121: 216-225.

Clifford GM, Smith JS, Plummer M, Muñoz N, Franceschi S 2003. Human papillomavirus types in invasive cervical cancer worldwide: a meta-analysis. Br J Cancer 88: 63-73. 
Daftarian P, Mansour M, Benoit AC, Pohajdak B, Hoskin DW, Brown RG, Kast WM 2006. Eradication of established HPV 16-expressing tumors by a single administration of a vaccine composed of a liposome-encapsulated CTL-T helper fusion peptide in a waterin-oil emulsion. Vaccine 24: 5235-5244.

de Jong A, van Poelgeest MI, van der Hulst JM, Drijfhout JW, Fleuren GJ, Melief CJ, Kenter G, Offringa R, van der Burg SH 2004. Human papillomavirus type 16-positive cervical cancer is associated with impaired CD4+ T-cell immunity against early antigens E2 and E6. Cancer Res 64: 5449-5455.

De Vuyst H, Clifford GM, Nascimento MC, Madeleine MM, Franceschi S 2008. Prevalence and type distribution of human papillomavirus in carcinoma and intraepithelial neoplasia of the vulva, vagina and anus: a meta-analysis. Int J Cancer 124: 1626-1636.

Diaz-Chavez J, Hernandez-Pando R, Lambert PF, Gariglio P 2008. Down-regulation of transforming growth factor- $\beta$ type II receptor (TGF- $\beta$ RII) protein and mRNA expression in cervical cancer. Mol Cancer 7: 3-14.

Dillner J, Arbyn M, Dillner L 2007. Translational mini-review series on vaccines: monitoring of human papillomavirus vaccination. Clin Exp Immunol 148: 199-207.

D’Souza G, Kreimer AR, Viscidi R, Pawlita M, Fakhry C, Koch WM, Westra WH, Gillison ML 2007. Case-control study of human papillomavirus and oropharyngeal cancer. $N$ Engl $J$ Med 356: 1944-1956.

Einstein MH, Kadish AS, Burk RD, Kim MY, Wadler S, Streicher H, Goldberg GL, Runowicz CD 2007. Heat shock fusion proteinbased immunotherapy for treatment of cervical intraepithelial neoplasia III. Gynecol Oncol 106: 453-460.

Ferguson M, Heath A, Johnes S, Pagliusi S, Dillner J 2006. Collaborative Study Participants. Results of the first WHO international collaborative study on the standardization of the detection of antibodies to human papillomaviruses. Int J Cancer 118: 1508-1514.

Fiander AN, Tristram AJ, Davidson EJ, Tomlinson AE, Man S, Baldwin PJ, Sterling JC, Kitchener HC 2006. Prime-boost vaccination strategy in women with high-grade, noncervical anogenital intraepithelial neoplasia: clinical results from a multicenter phase II trial. Int J Gynecol Cancer 16: 1075-1081.

Franco EL, Cuzick J, Hildesheim A, Sanjose S 2006. Issues in planning cervical cancer screening in the era of HPV vaccination. Vaccine 24 S3: 171-177.

Frattini MG, Lim HB, Doorbar J, Laimins LA 1997. Induction of human papillomavirus type 18 late gene expression and genomic amplification in organotypic cultures from transfected DNA templates. J Virol 71: 7068-7072.

Frazer IH, Quinn M, Nicklin JL, Tan J, Perrin LC, Ng P, O'Connor VM, White O, Wendt N, Martin J, Crowley JM, Edwards SJ, McKenzie AW, Mitchell SV, Maher DW, Pearse MJ, Basser RL 2004. Phase I study of HPV16-specific immunotherapy with E6E7 fusion protein and ISCOMATRIX adjuvant in women with cervical intraepithelial neoplasia. Vaccine 23: 172-181.

Future II Study Group 2007. Quadrivalent vaccine against human papillomavirus to prevent high-grade cervical lesions. $N$ Engl $J$ Med 356: 1915-1927.

Garcia F, Petry KU, Muderspach L, Gold MA, Braly P, Crum CP, Magill M, Silverman M, Urban RG, Hedley ML, Beach KJ 2004. ZYC101a for treatment of high-grade cervical intraepithelial neoplasia: a randomized controlled trial. Obstet Gynecol 103: 317-326.

Garland SM, Steben M, Hernandez-Avila M, Koutsky LA, Wheeler CM, Perez G, Harper DM, Leodolter S, Tang GW, Ferris DG, Esser MT, Vuocolo SC, Nelson M, Railkar R, Sattler C, Barr E, 012
Study Investigators 2007. Noninferiority of antibody response to human papillomavirus type 16 in subjects vaccinated with monovalent and quadrivalent L1 virus-like particle vaccines. Clin Vaccine Immunol 14: 792-795.

Giuliano AR, Tortolero-Luna G, Ferrer E, Burchell AN, de Sanjose S, Kjaer SK, Muñoz N, Schiffman M, Bosch FX 2008. Epidemiology of human papillomavirus infection in men, cancers other than cervical and benign conditions. Vaccine 26 (Suppl. 10): K17-28.

Gunn GR, Zubair A, Peters C, Pan ZK, Wu TC, Paterson Y 2001. Two Listeria monocytogenes vaccine vectors that express different molecular forms of human papilloma virus-16 (HPV-16) E7 induce qualitatively different $\mathrm{T}$ cell immunity that correlates with their ability to induce regression of established tumors immortalized by HPV-16. J Immunol 167: 6471-6479.

Hammes LS, Tekmal RR, Naud P, Edelweiss MI, Kirma N, Valente PT, Syrjänen KJ, Cunha-Filho JS 2007. Macrophages, inflammation and risk of cervical intraepithelial neoplasia (CIN) progressionclinicopathological correlation. Gynecol Oncol 105: 157-165.

Harmala LAE, Ingulli EG, Curtsinger JM, Lucido MM, Schmidt CS, Weigel BJ, Blazar BR, Mescher MF, Pennell CA 2002. The adjuvant effects of Mycobacterium tuberculosis Heat Shock Protein 70 Result from the rapid and prolonged activation of antigen-specific $\mathrm{CD}^{+}{ }^{+} \mathrm{T}$ Cells in vivo. J Immunol 169: 5622-5629.

Harper DM, Franco EL, Wheeler C, Ferris DG, Jenkins D, Schuind A, Zahaf T, Innis B, Naud P, De Carvalho NS, Roteli-Martins CM, Teixeira J, Blatter MM, Korn AP, Quint W, Dubin G, GlaxoSmithKline HPV Vaccine Study Group 2004. Efficacy of a bivalent $\mathrm{L} 1$ virus-like particle vaccine in prevention of infection with human papillomavirus types 16 and 18 in young women: a randomised controlled trial. Lancet 364: 1757-1765.

Harper DM, Franco EL, Wheeler CM, Moscicki AB, Romanowski B, Roteli-Martins CM, Jenkins D, Schuind A, Costa Clemens SA, Dubin G, HPV Vaccine Study group 2006. Sustained efficacy up to 4.5 years of a bivalent L1 virus-like particle vaccine against human papillomavirus types 16 and 18: follow-up from a randomised control trial. Lancet 367: 1247-1255.

Hasan UA, Bates E, Takeshita F, Biliato A, Accardi R, Bouvard V, Mansour M, Vincent I, Gissmann L, Iftner T, Sideri M, Stubenrauch F, Tommasino M 2007. TLR9 expression and function is abolished by the cervical cancer-associated human papillomavirus type 16. J Immunol 178: 3186-3197.

Hildesheim A, Herrero R, Wacholder S, Rodriguez AC, Solomon D, Bratti MC, Schiller JT, Gonzalez P, Dubin G, Porras C, Jimenez SE, Lowy DR, Costa Rican HPV Vaccine Trial Group 2007. Effect of human papillomavirus 16/18 L1 viruslike particle vaccine among young women with preexisting infection: a randomized trial. JAMA 298: 743-753.

Hirunpetcharat C, Wipasa J, Sakkhachornphop S, Nitkumhan T, Zheng YZ, Pichyangkul S, Krieg AM, Walsh DS, Heppner DG, Good MF 2003. CpG oligodeoxynucleotide enhances immunity against blood-stage malaria infection in mice parenterally immunized with a yeast-expressed $19 \mathrm{kDa}$ carboxyl-terminal fragment of Plasmodium yoelii merozoite surface protein-1 (MSP1(19)) formulated in oil-based Montanides. Vaccine 20: 2923-2932.

Hsieh CJ, Kim TW, Hung CF, Juang J, Moniz M, Boyd DA, He L, Chen PJ, Chen CH, Wu TC 2004. Enhancement of vaccinia vaccine potency by linkage of tumor antigen gene to gene encoding calreticulin. Vaccine 28: 3993-4001.

Hussain SF, Paterson Y 2005. What is needed for effective antitumor immunotherapy? Lessons learned using Listeria monocytogenes as a live vector for HPV-associated tumors. Cancer Immunol Immunother 54: 577-586. 
Joura EA, Leodolter S, Hernandez-Avila M, Wheeler CM, Perez G, Koutsky LA, Garland SM, Harper DM, Tang GW, Ferris DG, Steben M, Jones RW, Bryan J, Taddeo FJ, Bautista OM, Esser MT, Sings HL, Nelson M, Boslego JW, Sattler C, Barr E, Paavonen $\mathrm{J}$ 2007. Efficacy of a quadrivalent prophylactic human papillomavirus (types 6, 11, 16 and 18) L1 virus-like-particle vaccine against high-grade vulval and vaginal lesions: a combined analysis of three randomised clinical trials. Lancet 369: 1693-702.

Kaufmann AM, Nieland JD, Jochmus I, Baur S, Friese K, Gabelsberger J, Gieseking F, Gissmann L, Glasschröder B, Grubert T, Hillemanns P, Höpfl R, Ikenberg H, Schwarz J, Karrasch M, Knoll A, Küppers V, Lechmann M, Lelle RJ, Meissner H, Müller RT, Pawlita M, Petry KU, Pilch H, Walek E, Schneider A 2007. Vaccination trial with HPV16 L1E7 chimeric virus-like particles in women suffering from high grade cervical intraepithelial neoplasia (CIN 2/3). Int J Cancer 121: 2794-2800.

Kaufmann AM, Nieland J, Schinz M, Nonn M, Gabelsberger J, Meissner H, Müller RT, Jochmus I, Gissmann L, Schneider A, Dürst M 2001. HPV16 L1E7 chimeric virus-like particles induce specific HLA-restricted T cells in humans after in vitro vaccination. Int J Cancer 92: 285-293.

Kenter GG, Welters MJP, Valentijn ARPM, Löwik MJG, Berendsvan-der Meer DMA, Vloon APG, Drijfhout JW, Wafelman AR, Oostendorp J, Fleuren GJ, Offringa R, van der Burg SH, Melief CJM 2008. Phase I immunotherapeutic trial with long peptides spanning the E6 and E7 sequences of high-risk human papillomavirus 16 in end-stage cervical cancer patients shows low toxicity and robust immunogenicity. Clin Cancer Res 14: 169-177.

Kim D, Monie A, He L, Tsai YC, Hung CF, Wu TC 2008. Role of IL-2 secreted by PADRE-specific CD4+ T cells in enhancing E7specific CD8+ T-cell immune responses. Gene Ther 15: 677-687.

Kirma N, Hammes LS, Liu Y, Nair HB, Valente PT, Kumar S, Flowers LC, Tekmal RR 2007. Elevated expression of the oncogene c-fms and its ligand, the macrophage colony-stimulating factor- 1 , in cervical cancer and the role of transforming growth factor- $\beta 1$ in inducing C-FMS expression. Cancer Res 67: 1918-1926.

Koutsky L 1997. Epidemiology of genital human papillomavirus infection. Am J Med 102: 3-8.

Kumar S, Jones TR, Oakley MS, Zheng H, Kuppusamy SP, Taye A, Krieg AM, Stowers AW, Kaslow DC, Hoffman SL 2004. CpG oligodeoxynucleotide and Montanide ISA 51 adjuvant combination enhanced the protective efficacy of a subunit malaria vaccine. Infect Immun 72: 949-957.

Lehtinen M, Herrero R, Mayaud P, Barnabas R, Dillner J, Paavonen J, Smith P 2006. Studies to assess the long-term efficacy and effectiveness of HPV vaccination in developed and developing countries. Vaccine 24: 233-241.

Lin Y, Kwon T, Polo J, Zhu Y, Coates S, Crawford K, Dong C, Wininger M, Hall J, Selby M, Coit D, Medina-Selby A, McCoin C, Ng P, Drane D, Chien D, Han J, Vajdy M, Houghton M 2008. Induction of broad $\mathrm{CD}^{+}$and $\mathrm{CD}^{+} \mathrm{T}$-cell responses and crossneutralizing antibodies against hepatitis $\mathrm{C}$ virus by vaccination with Th1-adjuvanted polypeptides followed by defective alphaviral particles expressing envelope glycoproteins gpE1 and gpE2 and nonstructural proteins 3, 4, and 5. J Virol 82: 7492-7503.

Mazibrada J, Rittà M, Mondini M, De Andrea M, Azzimonti B, Borgogna C, Ciotti M, Orlando A, Surico N, Chiusa L, Landolfo S, Gariglio M 2008. Interaction between inflammation and angiogenesis during different stages of cervical carcinogenesis. Gynecol Oncol 108: 112-120.

Melief CJ 2008. Cancer immunotherapy by dendritic cells. Immunity 29: $372-383$

Müller M 2005. Codon optimization of papillomavirus genes. Methods Mol Med 119: 433-444.
Müller M, Zhou J, Reed TD, Rittmüller C, Burger A, Gabelsberger J, Braspenning J, Gissmann L 1997. Chimeric papillomavirus-like particles. Virology 234: 93-111.

Niederkorn JY 2008. Emerging concepts in CD8(+) T regulatory cells. Curr Opin Immunol 20: 327-331.

NIH 2009a. Clinicaltrial.org [homepage on the Internet]. Bethesda: A service of the U.S. National Institute of Health. A study of amolimogene (ZYC101a) in patients with high grade cervical intraepithelial lesions of the uterine cervix [updated $2009 \mathrm{Feb} 04$; cited 2009 Feb 04]. Available from: http://www.clinicaltrials.gov/ct2/ show/NCT00264732?term $=$ nct00264732\&rank $=1$.

NIH 2009b. Clinicaltrial.org [homepage on the Internet]. Bethesda: A service of the U.S. National Institute of Health. Immunotherapy of recurrent cervical cancers using dendritic cells (DCs) [updated 2009 Feb 04; cited 2009 Feb 04]. Available from: http://www.clinicaltrials.gov/ct2/show/NCT00155766?term=nc t00155766\&rank=1.

NIH 2009c. Clinicaltrial.org [homepage on the Internet]. Bethesda: A service of the U.S. National Institute of Health. MAGE-A3/ HPV 16 vaccine for squamous cell carcinoma of the head and neck [updated 2009 Feb 04; cited 2009 Feb 04]. Available from: http://www.clinicaltrials.gov/ct2/show/NCT00257738?term=nct 00257738\&rank=1.

NIH 2009d. Clinicaltrial.org [homepage on the Internet]. Bethesda: A service of the U.S. National Institute of Health. Surgery and vaccine therapy in treating patients with early cervical cancer [updated 2009 Feb 04; cited 2009 Feb 04]. Available from: http:// www.clinicaltrials.gov/ct2/show/NCT00002916?term $=$ NCT0000 2916\&rank=1.

Olsson SE, Villa LL, Costa RL, Petta CA, Andrade RP, Malm C, Iversen OE, Høye J, Steinwall M, Riis-Johannessen G, Andersson-Ellstrom A, Elfgren K, von Krogh G, Lehtinen M, Paavonen J, Tamms GM, Giacoletti K, Lupinacci L, Esser MT, Vuocolo SC, Saah AJ, Barr E 2007. Induction of immune memory following administration of a prophylactic quadrivalent human papillomavirus (HPV) types 6/11/16/18 L1 virus-like particle (VLP) vaccine. Vaccine 25: 4931-4939.

Paavonen J, Jenkins D, Bosch FX, Naud P, Salmeron J, Wheeler CM, Chow SN, Apter DL, Kitchener HC, Castellsague X, de Carvalho NS, Skinner SR, Harper DM, Hedrick JA, Jaisamrarn U, Limson GA, Dionne M, Quint W, Spiessens B, Peeters P, Struyf F, Wieting SL, Lehtinen MO, Dubin G, the HPV PATRICIA Study Group 2007. Efficacy of a prophylactic adjuvanted bivalent L1 virus-like-particle vaccine against infection with human papillomavirus types 16 and 18 in young women: an interim analysis of a phase III double-blind, randomised controlled trial. Lancet 369: 2161-2170.

Pahler JC, Tazzyman S, Erez N, Chen YY, Murdoch C, NOzawa H, Lewis CE, Hanahan D 2008. Plasticity in tumor promoting inflammation: impairment of macrophage recruitment evokes a compensatory neutrophil response. Neoplasia 10: 329-340.

Palefsky JM, Berry JM, Jay N, Krogstad M, Da Costa M, Darragh TM, Lee JY 2006. A trial of SGN-00101 (HspE7) to treat highgrade anal intraepithelial neoplasia in HIV-positive individuals. AIDS 20: 1151-1155.

Park JS, Kim EJ, Kwon HJ, Hwang ES, Namkoong SE, Um SJ 2000. Inactivation of interferon regulatory factor-1 tumor suppressor protein by HPV E7 oncoprotein. Implication for the E7-mediated immune evasion mechanism in cervical carcinogenesis. $J$ Biol Chem 275: 6764-6769.

Pedersen C, Petaja T, Strauss G, Rumke HC, Poder A, Richardus JH, Spiessens B, Descamps D, Hardt K, Lehtinen M, Dubin G, HPV Vaccine Adolescent Study Investigators Network 2007. Immu- 
nization of early adolescent females with human papillomavirus type 16 and $18 \mathrm{~L} 1$ virus-like particle vaccine containing AS04 adjuvant. J Adolesc Health 40: 564-571.

Phelps WC, Howley PM 1987. Transcriptional trans-activation by the human papillomavirus type 16 E2 gene product. J Virol 61: 1630-1638.

Poggi A, Zocchi MR 2008. Role of bone marrow stromal cells in the generation of human $\mathrm{CD} 8+$ regulatory T cells. Hum Immunol 69: 755-759.

Reisinger KS, Block SL, Lazcano-Ponce E, Samakoses R, Esser MT, Erick J, Puchalski D, Giacoletti KE, Sings HL, Lukac S, Alvarez FB, Barr E 2007. Safety and persistent immunogenicity of a quadrivalent human papillomavirus types $6,11,16,18 \mathrm{~L} 1$ virus-like particle vaccine in preadolescents and adolescents: a randomized controlled trial. Pediatr Infect Dis J 26: 201-209.

Ritz U, Momburg F, Pilch H, Huber C, Maeurer MJ, Seliger B 2001. Deficient expression of components of the MHC class I antigen processing machinery in human cervical carcinoma. Int $J$ Oncol 19: $1211-1220$.

Roman LD, Wilczynski S, Muderspach LI, Burnett AF, O’Meara A, Brinkman JA, Kast WM, Facio G, Felix JC, Aldana M, Weber JS 2007. A phase II study of Hsp-7 (SGN-00101) in women with high-grade cervical intraepithelial neoplasia. Gynecol Oncol 106: 558-566.

Ronco LV, Karpova AY, Vidal M, Howley PM 1998. Human papillomavirus 16 E6 oncoprotein binds to interferon regulatory factor-3 and inhibits its transcriptional activity. Genes Dev 12: 2061-2072.

Schiffman M, Kjaer SK 2003. Chapter 2: natural history of anogenital human papillomavirus infection and neoplasia. J Natl Cancer Inst Monogr 31: 14-19.

Schiller JT, Roden RBS 1995. Papillomavirus-like particles. Papillomavirus Rep 6: 121-128.

Schlecht NF, Platt RW, Duarte-Franco E, Costa MC, Sobrinho JP, Prado JC, Ferenczy A, Rohan TE, Villa LL, Franco EL 2003. Human papillomavirus infection and time to progression and regression of cervical intraepithelial neoplasia. $J$ Natl Cancer Inst Monogr 95: 1336-1343.

Schwarz TF, Leo O 2008. Immune response to human papillomavirus after prophylactic vaccination withAS04-adjuvanted HPV-16/18 vaccine: improving upon nature. Gynecol Oncol 110 (Suppl. 1): S1-10.

Sewell DA, Shahabi V, Gunn GR 3rd, Pan ZK, Dominiecki ME, Paterson Y 2004. Recombinant Listeria vaccines containing PEST sequences are potent immune adjuvants for the tumor-associated antigen human papillomavirus-16 E7. Cancer Res 64: 8821-8825.

Srivastava P 2002. Interaction of heat shock proteins with peptides and antigen presenting cells: chaperoning of the innate and adaptive immune responses. Annu Rev Immunol 20: 395-425.

Stanley M, Villa LL 2008. Monitoring HPV vaccination. Vaccine (Suppl. 1): A24-27.

Stanley MA, Pett MR, Coleman N 2007. HPV: from infection to cancer. Biochem Soc Trans 35: 1456-1460.

Sutter G, Moss B 1992. Nonreplicating vaccinia vector efficiently expresses recombinant genes. Proc Natl Acad Sci USA 89: 10847-10851.

Syrjanen S 2005. Human papillomavirus (HPV) in head and neck cancer. J Clin Virol 32 (Suppl. 1): S59-S66.
Vandepapeliere P, Barrasso R, Meijer CJ, Walboomers JM, Wettendorff M, Stanberry LR, Lacey CJ 2005. Randomized controlled trial of an adjuvanted human papillomavirus (HPV) type 6 L2E7 vaccine: infection of external anogenital warts with multiple HPV types and failure of therapeutic vaccination. $J$ Infect Dis 192: 2099-107.

Villa LL, Ault KA, Giuliano AR, Costa RL, Petta CA, Andrade RP, Brown DR, Ferenczy A, Harper DM, Koutsky LA, Kurman RJ, Lehtinen M, Malm C, Olsson SE, Ronnett BM, Skjeldestad FE, Steinwall M, Stoler MH, Wheeler CM, Taddeo FJ, Yu J, Lupinacci L, Railkar R, Marchese R, Esser MT, Bryan J, Jansen KU, Sings HL, Tamms GM, Saah AJ, Barr E 2006a. Immunologic responses following administration of a vaccine targeting human papillomavirus types $6,11,16$, and 18. Vaccine 24: 5571-5583.

Villa LL, Costa RL, Petta CA, Andrade RP, Ault KA, Giuliano AR, Wheeler CM, Koutsky LA, Malm C, Lehtinen M, Skjeldestad FE, Olsson SE, Steinwall M, Brown DR, Kurman RJ, Ronnett BM, Stoler MH, Ferenczy A, Harper DM, Tamms GM, Yu J, Lupinacci L, Railkar R, Taddeo FJ, Jansen KU, Esser MT, Sings HL, Saah AJ, Barr E 2005. Prophylactic quadrivalent human papillomavirus (types 6,11, 16, and 18) L1 virus-like particle vaccine in young women: a randomised double-blind placebo-controlled multicentre phase II efficacy trial. Lancet Oncol 6: 271-278.

Villa LL, Costa RL, Petta CA, Andrade RP, Paavonen J, Iversen OE, Olsson SE, Høye J, Steinwall M, Riis-Johannessen G, AnderssonEllstrom A, Elfgren K, Krogh G, Lehtinen M, Malm C, Tamms GM, Giacoletti K, Lupinacci L, Railkar R, Taddeo FJ, Bryan J, Esser MT, Sings HL, Saah AJ, Barr E 2006b. High sustained efficacy of a prophylactic quadrivalent human papillomavirus types 6/11/16/18 L1 virus-like particle vaccine through 5 years of follow-up. Br J Cancer 95: 1459-1466.

Wan YY, Flavell RA 2008. TGF-beta and regulatory T cell in immunity and autoimmunity. $J$ Clin Immunol 28: 647-659.

Wang SS, Hildesheim A 2003. Chapter 5: Viral and host factors in human papillomavirus persistence and progression. J Natl Cancer Inst Monogr 31: 35-40.

Welters MJP, Kenter GG, Piersma SJ, Vloon APG, Löwik MJG, Berends-van-der Meer DMA, Drijfhout JW, Valentijn ARPM, Wafelman AR, Oostendorp J, Fleuren GJ, Offringa R, Melief CJM, van der Burg SH 2008. Induction of tumor-specific $\mathrm{CD}^{+}$ and $\mathrm{CD} 8^{+} \mathrm{T}$-cell immunity in cervical cancer patients by human papillomavirus type 16 E6 and E7 long peptides vaccine. Clin Cancer Res 14: 178-187.

WHO - World Health Organization [homepage on the Internet], Geneva. WHO HPV LabNet 2008 [updated 18 December 2008; cited 04 February 2009]. Available from: http://www.who.int/biologicals/areas/vaccines/hpv_labnet/en/index.html.

Wu T-C, Guarnieri FG, Staveley-O'Carroll KF, Viscidi RP, Levitsky HI, Hedrick L, Cho KR, August T, Pardoll DM 1995. Engineering an intracellular pathway for MHC class II presentation of HPV-16 E7. Proc Natl Acad Sci USA 92: 11671-11675.

Zhou J, Gissmann L, Zentgraf H, Müller H, Picken M, Müller M 1995. Early phase in the infection of cultured cells with papillomavirus virion. Virology 214: 167-176.

Zwaveling S, Mota SCF, Nouta J, Johnson M, Lipford GB, Offringa R, van der Burg SH, Melief CJM 2002. Established human papillomavirus type 16-expressing tumors are effectively eradicated following vaccination with long peptides. J Immunol 169: 350-358. 